\title{
Analysis of leaf flavonoid composition of some Iranian Cotoneaster Medik. (Rosaceae) species
}

\author{
Zeynab Lotfi, Fahimeh Salimpour*, Fariba Sharifnia, Sedigheh Arbabian, Maryam Peyvandi
}

\author{
Department of Biology, Tehran North Branch, Islamic Azad University \\ Vafadar Blv., Shahid Sadoghi St, Hakimieh, Tehran, Iran \\ *E-mail: fahimehsalimpour89@gmail.com
}

\begin{abstract}
The genus Cotoneaster consists of unarmed shrubs that naturally distributed in north parts of Iran. It is a problematic genus, and there are many discussions about its species number in Iran as well the World. Recently, M Khatamsaz has been listed 19 species of it in Iran. In the current research, we studied leaf flavonoid composition of seven Cotoneaster species from Iran. These species were harvested from the northern provinces of the country and their leaf ethanolic extracts were subjected to HPLC, for detection the types and amounts of their flavonoid compounds. We identified four flavonoid compounds: rutin, myricetin, quercetin, and kaempferol. The concentration of these flavonoids differed between the species, moreover amount of each flavonoid also varied among the studied species. All of them were registered in the studied species, except for myricetin, which was not observed in C. nummularius. The highest amount of flavonoids were detected in C. nummularius, while $C$. discolor had the lowest one. The evaluated species divided into four distinct group in UPGMA tree. According to CA-Joined plot, each group was characterized by species amount of flavonoid(s). All of evaluated species belonged to the same section of the genus, therefore our findings revealed that the flavonoid data were useful at sectional level for identification of the species.
\end{abstract}

Key words: chemotaxonomy; Cotoneaster; flavonoids; species

\section{Introduction}

The genus Cotoneaster Medik. belongs to the tribe Pyreae of the subfamily Spiraeoideae-Rosaceae (Potter et al. 2007). Its species number varies and ranges from about 50 to over 400 (Niaki et al. 2019). According to previous evaluations (Marshall and Brown 1981; Nogler 1984), the most prominent reason for the wide range of species number was the asexual seed production (apomixes) that is often associated with hybridization and polyploidy.

Dickoré and Kasperek (2010) have suggested that Cotoneaster distribution is often scattered and mainly concentrated in the mountains of the meridional and nemoral zones, while its center of diversity is in China and the Himalayas.

Cotoneasteris a problematic genus, mainly because it comprises nearly 500 published binomials. Riedl (1969) listed 14 species in Iran, but Khatamsaz (1992) introduced 19 species. In Iran, these species are mainly distributed in the Alborz Mountains, high elevations in the northwest and northeast of the country (Raei Niaki et al. 2009; Raei Niaki et al. 2019).

The genus includes numerous ornamentals, which are widely cultivated in landscaping for their attractive flowers and fruit (Bailey and Bailey 1976). Moreover, several species of the genus, for example C. melanocarpus Lodd., C. nummularia Fisch. et Mey, and C. tricolor Pajork, are used in folk medicine, in different parts of the world, to treat various disorders such as nasal hemorrhage, excessive menstruation, hematemesis, neonatal jaundice, fever and cough (Holzer et al. 2013; Esmaeili et al. 2015). It is important to know that most of these properties can be attributed to the presence of low-molecular weight polyphenols including simple phenolic acids and flavonoids (Khan et al. 2009; Sati et al. 2010).

Flavonoids are considered as polyphenolic secondary metabolites that play different roles in plants. These compounds are involved in the production of flower pigments and also in plant protection from various pathogens. For example, some kinds of flavonoids are antifungal and antibacterial agents, while other types have significant roles in the plants protection from insects and herbivorous mammals (Harborne and Williams 2000).

The chemical stability and widespread occurrence make the flavonoids as chemical markers in the classification of plants and they are considered as a useful tool for identification and taxonomy of higher plants (Noori et al. 2015a, b; Noori and Talebi 2017).

For these reasons, in the current study we investigated leaf flavonoid compounds of seven Iranian species of Cotoneaster in order to identify their flavonoid compounds and species relationship based on these data. As far as we could search, no similar previous study was found on these species in Iran. 


\section{Material and method}

\section{Plant materials}

Plant samples of seven Cotoneaster species were harvested from natural populations in two provinces of northern Iran (Table 1) and were identified according to descriptions provided in Flora of Iran (Khatamsaz 1992) and Flora of USSR (Pojarkova 1941). One of the collected samples did not match with descriptions in Flora of Iran and Flora of USSR, and it seems that the sample belongs to a new species of Cotoneaster from Iran. Therefore, we decide to definite it as C. new, until its legal name is validate. Voucher specimens were deposited at Herbarium of Islamic Azad University Tehran (IAUNT).

Table 1. Localities and herbarium numbers of the studied species of Cotoneaster.

\begin{tabular}{|c|c|c|}
\hline Species & Localities, elevation a.s.l. & Voucher No. \\
\hline C. discolor Pojark. & Mazandaran province, 72 km Varsk- Firouzkoh, 3346 m & AUNT-17413 \\
\hline C. insignis Pojark. & Golestan province, Kolaleh, Aziz Abad, 1140 m & AUNT-17406 \\
\hline $\begin{array}{l}\text { C. kotschyi Klotz, } \\
\text { Wissensch. Zeitschr. }\end{array}$ & Golestan province, Til Abad, Khosh Yeylagh, 1570 m & AUNT- 17408 \\
\hline C. morrisonensis Hayata. & Golestan province, Til Abad, Khosh Yeylagh, 1570 m & AUNT-17418 \\
\hline C. morulus Pojark. & Mazandaran province, Avard, Galogah, 1217 m & AUNT-17411 \\
\hline C. new & Mazandaran province, Pole Akhondi, Galogah, 1034 m & AUNT-17421 \\
\hline $\begin{array}{l}\text { C. nummularius Fisch. \& } \\
\text { C.A Mey. }\end{array}$ & Mazandaran, Sefidchah, Galogah, 1054 m & AUNT-17414 \\
\hline
\end{tabular}

\section{Preparation of Plant Extracts}

About $0.5 \mathrm{~g}$ of fine powdered leaf sample of each species were extracted with $5 \mathrm{ml} \mathrm{HPLC}$ methanol (80\%) through open reflux process at $40{ }^{\circ} \mathrm{C}$ for $24 \mathrm{~h}$. Then the extracts were filtered through filter paper to remove free unextractable substances. The filtrates solution of plant extracts were preserved $4{ }^{\circ} \mathrm{C}$ for further process.

\section{HPLC Analysis}

The HPLC analysis of the extract was performed with Chromatographic system (Agilent - infinity II). The separation was performed on a SGE Protecol PC18GP120 $(250 \mathrm{~mm} \times 4.6 \mathrm{~mm}, 5 \mu \mathrm{m})$ column at ambient temperature. The mobile phase consists of methanol to water $\left(70: 30 \mathrm{v} \mathrm{v}^{-1}\right)$ and the separations were performed by using isocratic mode, elution performed at a flow rate of $1 \mathrm{ml} \mathrm{min} \mathrm{m}^{-1}$. The samples were run for $15 \mathrm{~min}$ and detection was done at $352 \mathrm{~nm}$ by UV detector. Rutin was used as standard and flavonoid content was determined as rutin equivalent. For this purpose, a calibration curve for rutin was drawn. From the standard rutin solution the dilutions of $0.080,0.040,0.064$, and $0.126 \mathrm{mg} \mathrm{ml}^{-1}$ concentrations were prepared in methanol.

\section{Statistical analysis}

For clustering of the investigated species, the flavonoid data were standardized (mean $=0$, variance $=1$ ) and used for multivariate analyses, including UPGMA (Unweighted Pair-Group Method with Arithmetic mean) and Correspondence analysis (CA-joined plot). Plots clustering were performed in Multivariate Statistical Package (MVSP) software (Podani 2000).

\section{Results}

The extracted flavonoids extracted from species leaves were presented in Table 2. Among the studied species, $C$. nummularius had the highest total amount of flavonoids, while $C$. discolor. had the lowest total amount. Kaempferol and myricetin were the most and less abundant flavonoids respectively.

Table 2. Flavonoid compounds were found from methanolic extract of leaves (all values are $\mathrm{mg} \mathrm{g}^{-1} \mathrm{dried}^{\text {tissue). }}$

\begin{tabular}{lllll}
\hline Species & Rutin & Myricetin & Quercetin & Kaempferol \\
\hline C. discolor & 11.99 & 0.13 & 7.24 & 0.14 \\
C. insignis & 16.75 & 0.06 & 34.10 & 0.06 \\
C. kotschyi & 7.94 & 4.06 & 7.14 & 0.89 \\
C. morrisonensis & 9.61 & 4.72 & 7.13 & 0.47 \\
C. morulus & 6.30 & 2.32 & 255.51 & 0.10 \\
C. new & 13.98 & 5.13 & 417.92 & 0.32 \\
C. nummularius & 10.58 & $\mathrm{n} / \mathrm{a}$ & 4.00 & 7516.7 \\
\hline
\end{tabular}


The highest (16.75 $\left.\mathrm{mg} \mathrm{g}^{-1}\right)$ and lowest ( $\left.6.30 \mathrm{mg} \mathrm{g}^{-1}\right)$ amounts of rutin were registered in $C$. insignis and C. morulus, respectively. Myricetin was not observed in C. nummularius, while its highest amount was reported from $C$. new (5.13 mg $\left.\mathrm{g}^{-1}\right)$. Moreover, $C$. new had the highest amount $\left(417.92 \mathrm{mg} \mathrm{g}^{-1}\right)$ of quercetin, whereas the lowest amount $\left(4.00 \mathrm{mg} \mathrm{g}^{-1}\right)$ of it was registered from $C$. nummularius. We recorded the largest amount $\left(7516.7 \mathrm{mg} \mathrm{g}^{-1}\right)$ of kaempferol in $C$. nummularius, whereas $C$. insignis had the lowest amount (0.06 $\left.\mathrm{mg} \mathrm{g}^{-1}\right)$ (Fig.1).

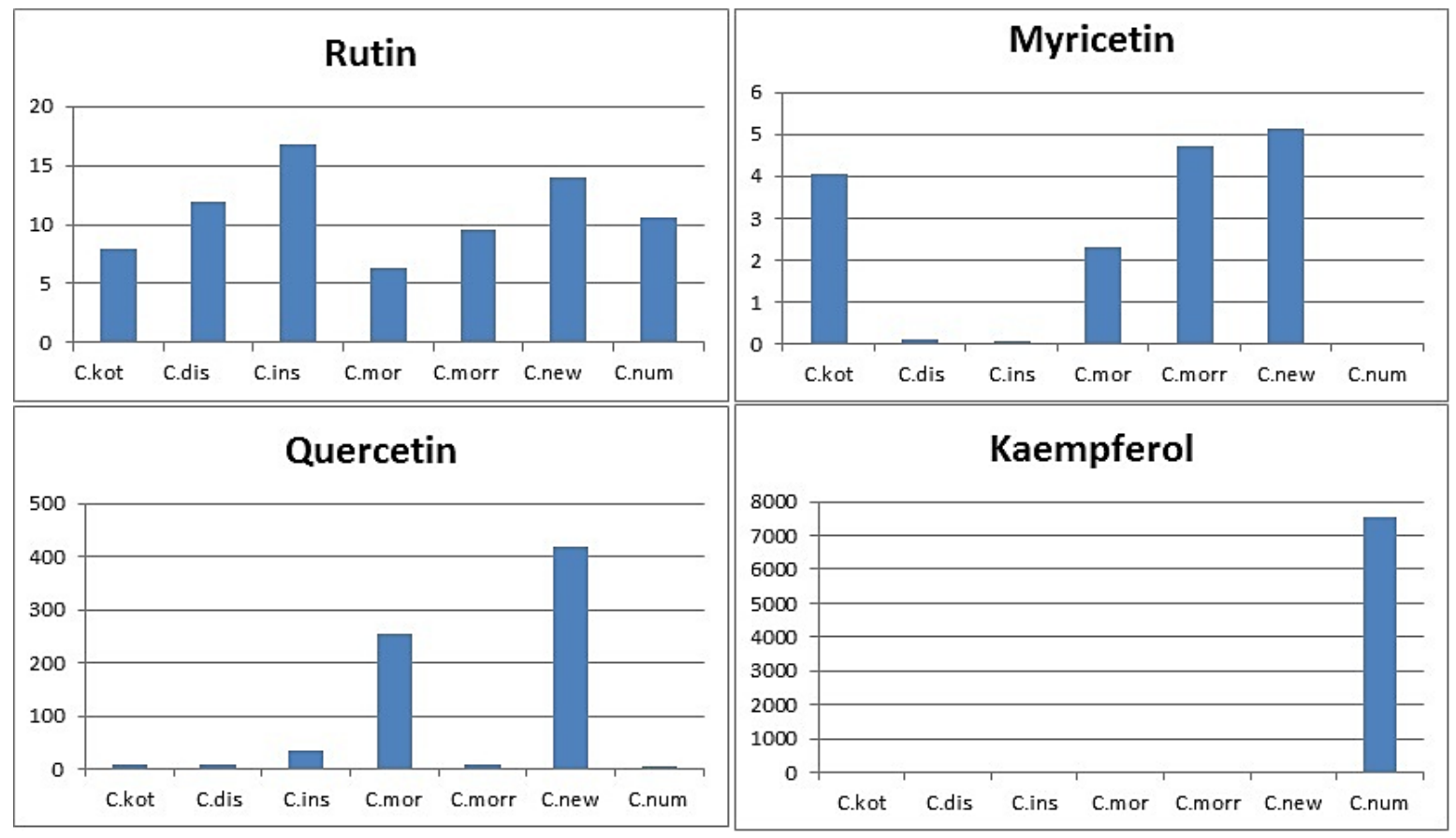

Fig. 1 Pattern of flavonoids existence among the studied Cotoneaster species.

The studied species were clustered in UPGMA tree of phytochemical data (Fig. 2). The tree had two clades: $C$. nummularius placed separately in the small clade, while the rest populations were in the large clade, which were divided into two branches. One branch was consisted of $C$. new and $C$. morulus, while another one had two groups. $C$. insignis was registered in a group, however the rest species place closely in another group. Therefore, the studied species were observed in four groups.

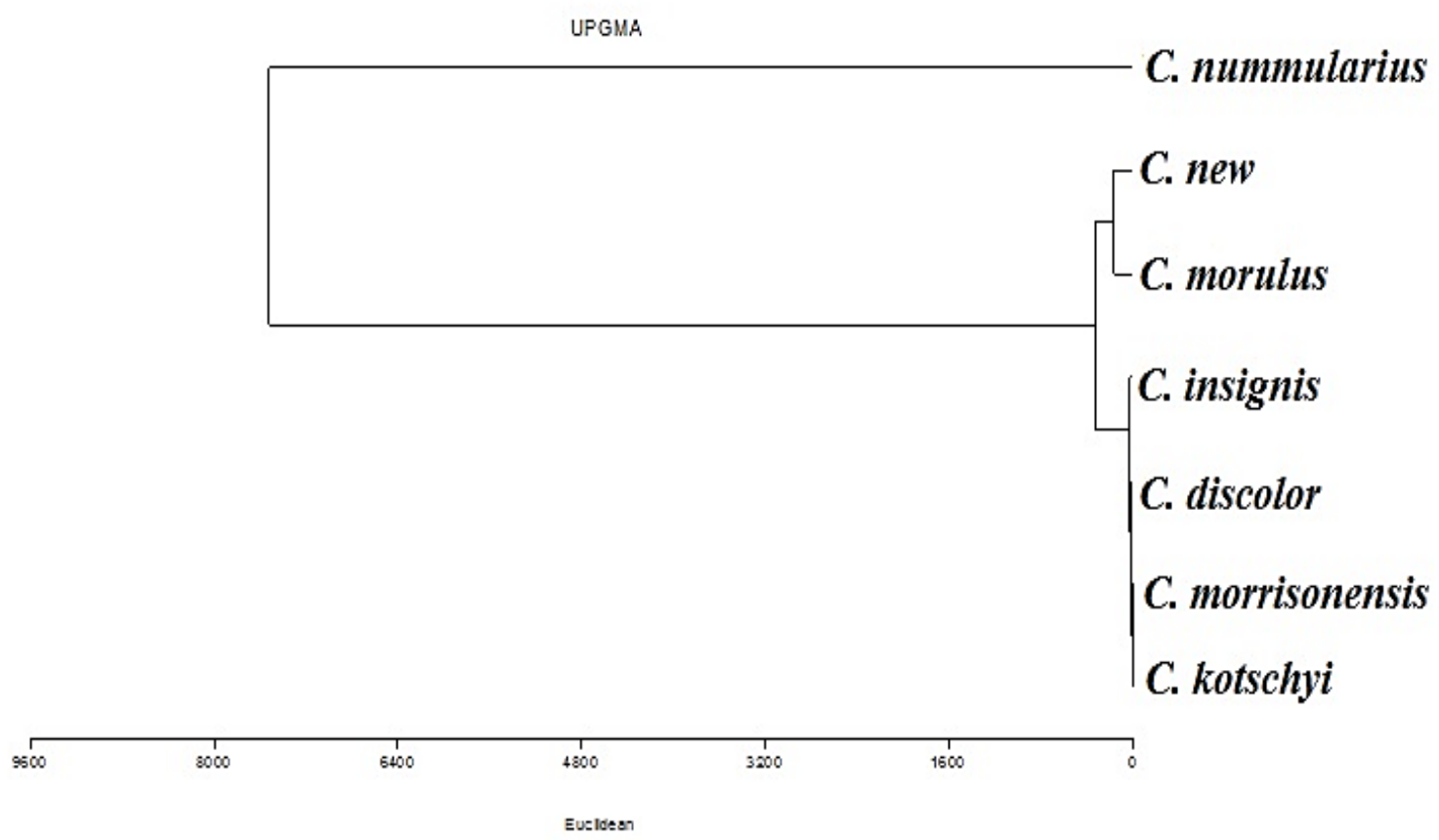

Fig. 2 UPGMA tree of the studied species according to phytochemical data 
Ca-joined plot revealed these group had species flavonoid type that was useful in identification of them. For example, C. nummularius was characterized by kaempferol, or $C$. morulus and $C$. new had the highest amount of quercetin (Fig. 3).

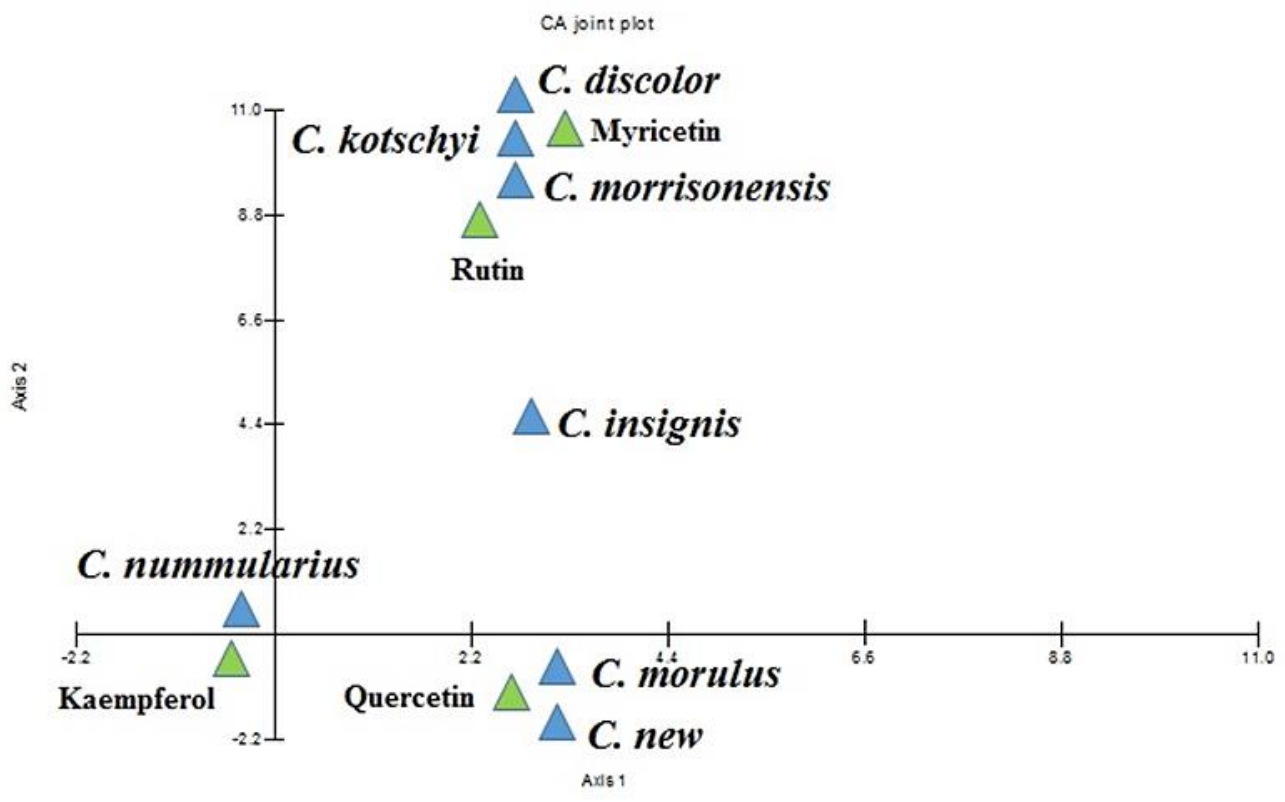

Fig. 3 CA- joined plot of the phytochemical data and species (the blue and greed symbols are species and chemical compounds, respectively).

\section{Discussion}

In the current study, we detected flavonoids from the leaf ethanolic extract of seven Iranian Cotoneaster species. In total, four flavonoids were identified: myricetin, kaempferol, rutin, and quercetin. All of these flavonoids belong to flavonols subgroup. Flavonoids can be divided into several subgroups according to the substitution patterns of the ring $C$, and flavonoids within the same class can be differentiated by the substitution of $A$ and $B$. These subgroups are: flavonoids, flavanones, isoflavonoids, flavones, flavans-3-ol, and anthocyanins (Prasain et al. 2010; Havsteen 2002).

According to previous studies, these flavonoids have several medicinal properties. For example, Godse et al. (2010) have suggested that myricetin has antihypertensive effect. This flavonoid hindered the progression of high blood pressure and also turned the metabolic alternations in rats on fructose-induced diet. In addition, according to Chang et al. (2012) findings myricetin suppresses body weight increment and accumulation of fat by maximizing the fatty acids oxidation that was due to enhance the regulation of hepatic peroxisome proliferator activated receptor and decrease the regulation of hepatic sterol regulatory element- binding protein expressions in rats on high fat diet.

Kaempferol was the most abundant flavonoid among the studied species. Previous investigations (Vinson et al. 1995; Asif and Khodadadi 2013) have revealed that kaempferol has various properties such as inhibitory effect on HIV protease, anti-inflammatory, antioxidant, antiulcer activity and antitumor.

Quercetin was the second most abundant flavonoid in our studied species. It is the most active flavonoid and many medicinal plants owe their functions to their high content of this flavonoid. Lim et al. (2007) have believed that the significant anti-inflammatory property of this compound is related to direct inhibition of the inflammation initial processes. Moreover, investigations have revealed that quercetin has anticancer property, including in inhibiting the proliferation and also migration of cancer cell.

Rutin is a more effective antioxidant than vitamins and has antioxidant and free radical scavenging effect in foods (Vinson et al. 1995; Hollman et al. 1997). Rutin and quercetin were extracted from leaf extracts of several Cotoneaster species such as C. zabelii, C. bullatus, C. splendens, C. dielsianus, C. hjelmqvistii, C. horizontalis, C. divaricatus, C. Iucidus, C. melanocarpus, C. tomentosus, and C. integerrimus (Kicel et al. 2016).

According to UPGMA tree of flavonoids data, the studied species were divided into four groups. Group I including $C$. nummularius, group II had $C$. new and $C$. morulus, group III consisted of $C$. insignis and group IV has been consisted of C. discolor, C. kotschyi and C. morrisonensis. CA-Joined plot revealed that each of these groups had specific compound(s) that was useful in identification of them. This results revealed that the flavonoid data are useful in identification of species of the genus. In addition, all of our examined species belonged to the same section of Cotoneaster, therefore flavonoids can be used as the phytochemical marker in sectional level of the genus. Our findings were in agreement with previous similar works. Webb and Harborne (1991) have suggested that flavonoid data were meaningful in infra-generic classification of the plants, especially at sectional level. In addition, it is well revealed that the flavonoid data on flowering plants are often of value for resolving the evolutionary relationships among the taxa (Markham et al. 1970). For instance, flavonoid data can be used as a taxonomic features of the genus Chromolaena, and the chemotaxonomic significance of 
these compounds was useful for resolving the infra-generic complexity of the genus (de Oliveira et al. 2017). Furthermore, Braunberger et al. (2015) have reported that flavonoids were used as chemotaxonomic characteristics in Drosera for the species classification in sections and for the improvement of infra-generic taxonomy in this genus.

As mentioned in material and methods section, one of plant samples that was harvested from Mazandaran province did not morphologically match with the descriptions of identified Cotoneaster species in Iran and neighboring countries. Therefore, we considered it as a new species for Iran and contemporary definite it as $C$. new. In present study, this species closely grouped with $C$. morulus, according to flavonoid data. The harvesting localities of these species are close to each other, so there can be two issues in this regard. (1) C. new can be a population of $C$. morulus, which is very distinct in the morphological characteristics, or (2) it is a new species of the genus for Iran created by the sympatric speciation. However, further molecular, cytological, anatomical, and palynological investigations is needed to verify this.

Christensen (1992) has stated that several new species have been described from North America by taxonomists, and Cotoneasterhas more than 1000 species. Nevertheless, the current number of accepted species is about 200 and many of the described taxa have been recently reduced to synonyms. According to Dönmez (2004) suggestion, polymorphism, hybridization, and apomictic breeding strategies caused great differences among the populations of Cotoneaster species. Therefore, most of the taxa described by taxonomists should be regarded as synonyms because of genus diverse nature.

\section{References}

Asif M, Khodadadi E. 2013. Medicinal uses and chemistry of flavonoid contents of some common edible tropical plants. Journal of Paramedical Sciences 4: 119-138.

Bailey LH, Bailey EZ. 1976. Hortus: A concise dictionary of plants cultivated in the United States and Canada. Third edition. NY: Macmillan General Reference.

Braunberger C, Zeh M, Conrad J, Wawrosch C, Strohbach J, Beifuss U, Krenn L. 2015. Flavonoids as chemotaxonomic markers in the genus Drosera. Phytochemistry 118: 74-82. doi: 10.1016/j.phytochem.2015.08.017

Chang CJ, Tzeng TF, Liou SS, Chang YS, Liu IM. 2012. Myricetin increases hepatic peroxisome proliferator activated receptor protein expression and decreases plasma lipids and adiposity in rats. Evid. Based Complement Alternat Med 11: Article ID 787152. Doi: 10.1155/2012/787152

Christensen, K.I. 1992. Revision of Crataegus Sect. Crataegus and Nothosect. Crataeguineae (Rosaceae-Maloideae) in the Old World. Systematic Botany Monographs 35: 199. Doi: $10.2307 / 25027810$

Dickoré WB, Kasperek G. 2010. Species of Cotoneaster (Rosaceae, Maloideae) indigenous to, naturalising or commonly cultivated in Central Europe. Willdenowia 40: 13-43. Doi: $10.3372 /$ wi.40.40102

De Oliveira JAM, Bernardi DI, Balbinot RB, Silva Avíncola A, da Pilau E, do Carmo MRB, Sarragiotto MH, Baldoqui DC. 2017. Chemotaxonomic value of flavonoids in Chromolaena congesta (Asteraceae). Biochem. Syst. Ecol. 70: 7-13. Doi: 10.1016/j.bse.2016.10.013

Dönmez AA. 2004. The Genus Crataegus L. (Rosaceae) with Special Reference to Hybridisation and Biodiversity in Turkey. Turk J Bot 28:29-37

Esmaeili S, Ghiaee A, Naghibi F, Mosaddegh M. 2015. Antiplasmodial activity and cytotoxicity of plants used in traditional medicine of Iran for the treatment of fever. Iran J. Pharm. Res. 14: 103-107.

Godse S, Mohan M, Kasture V, Kasture S. 2010. Effect of myricetin on blood pressure and metabolic alterations in fructose hypertensive rats. Pharm. Biol. 48: 494-498. Doi: 10.3109/13880200903188526

Harborne J, Williams C. 2000. Advances in flavonoid research since 1992. Phytochemistry 55: 481-504. Doi: 10.1016/S00319422(00)00235-1

Havsteen BH. 2002. The biochemistry and medical significance of the flavonoids. Pharmacol. Ther 96: 67-202. Doi: 10.1016/S0163-7258(02)00298-X

Hollman PCH, Van Trijp JMP, Buysman MNCP, Gaag MSVD, Mengelers MJB, De Vries JHM, Katan MB. 1997. Relative bioavailability of the antioxidant flavonoid quercetin from various foods in man. FEBS Lett. 418: 152-156. Doi: $\underline{10.1016 / \text { S0014-5793(97)01367-7 }}$

Holzer VMD, Lower-Nedza AD, Nandintsetseg M, Batkhuu J, Brantner AH. 2013. Antioxidant constituents of Cotoneaster melanocarpus Lodd. Antioxidants 2: 265-272. Doi: 10.3390/antiox2040265

Khan S, Riaz N, Afza N, Malik A, Aziz-ur-Rehman, Iqbal L, Lateef M. 2009. Antioxidant constituents from Cotoneaster racemiflora. J. Asian Nat. Prod. Res. 11: 44-48. Doi: 10.1080/10286020802435745

Khatamsaz M. 1992. Cotoneaster Medik. In: Assadi M (ed.) Flora of Iran, no. 6. Research institute of forests and rangelands.

Lim JH, Park JW, Min DS, Chang JS, Lee YH, Park YB, Choi KS, Kwon TK. 2007. NAG-1 up-regulation mediated by EGR-1 and p53 is critical for quercetin-induced apoptosis in HCT116 colon carcinoma cells. Apoptosis 12: 411-21. Doi: $\underline{10.1007 / s 10495-006-0576-9}$

Markham KR, Mabry TJ, Swift WT. 1970. Distribution of flavonoids in the genus Baptisia (Leguminosae). Phytochemistry 9: 2359-2364. Doi: 10.1016/S0031-9422(00)85740-4

Marshall DR, Brown AHD. 1981. The evolution of apomixis. Heredity 47: 1-15. Doi: 10.1038/hdy.1981.54

Nogler GA. 1984. Gametophytic apomixis. In: Johri BM, editor. Embryology of angiosperms. Berlin: Springer-Verlag, p. 475518. Doi: $10.1007 / 978-3-642-69302-1 \_10$ 
Noori M, Talebi SM. 2017. A chemotaxonomic study of some Iranian Linum taxa. Phytologia Balcanica 23(1): $23-29$.

Podani J. 2000. Introduction to the exploration of multivariate biological data. Leiden.

Pojarkova AI. 1941. Crataegus L. In: Komarov VL and Yuzepchuk SV, editors.. Flora USSR IX: 317-356. Moscow and Leningrad: Botanicheskii Institut Akademii Nauk SSSR (Translated from Russian by Israel Program for Scientific Translations. Jerusalem 1971).

Potter D, Eriksson T, Evans RC, Oh SH, Smedmark JEE, Morgan DR, Kerr M, Robertson KR, Arsenault MP, Dickinson TA, Campbell CS. 2007. Phylogeny and classification of Rosaceae. Plant Systematics and Evolution 266: 5-43. Doi: 10.1007/s00606-007-0539-9

Prasain J, Carlson S, Wyss J. 2010. Flavonoids and age-related disease: Risk, benefits and critical windows. Maturitas 66 : 163-171. Doi: $10.1016 /$ j.maturitas.2010.01.010

Raei Niaki, N., Attar, F., Maroofi, H. (2009). Anatomical studies on fourteen species of the genus Cotoneaster Medik. (Rosaceae) in Iran. Iranian Journal of Botany 15: 96-104.

Raei Niaki N, Attar F, Mirtadzadini M, Mahdigholi K, Sheidai M. 2019. Micromorphological studies of leaf epidermis on the genus Cotoneaster Medik in Iran and its implication. Nordic Journal of Botany 37(2). Doi: 10.1111/njb.02074

Riedl H. 1969. Cotoneaster. In: Rechinger KH, editor. Flora Iranica, No. 66, Graz, p. 13-26.

Sati SC, Sati M, Sharma A, Joshi M. 2010. Isolation and characterisation of phenolics from the roots of Cotoneaster acuminatus and determination of their antimicrobial activity. Int. J. Pharm. Pharm. Sci. 2: 58-60.

Vinson JA, Dabbagh YA, Serry MM, Jang J. 1995. Plant flavonoids, especially tea flavonols, are powerful antioxidants using an in vitro oxidation model for heart disease. J. Agric. Food Chem. 43: 2800-2804. Doi: 10.1021/jf00059a005

Webb ME, Harborne JB. 1991. Leaf flavonoid aglycone patterns and sectional classification in the genus Vicia (Leguminosae). Biochem Syst Ecol. 19: 81-86. Doi: 10.1016/0305-1978(91)90115-G

\section{Citation:}

Lotfi Z, Salimpour F, Sharifnia F, Arbabian S, Peyvandi M. 2019. Analysis of leaf flavonoid composition of some Iranian Cotoneaster Medik. (Rosaceae) species. Acta Biologica Sibirica 5(4): 54-59.

Submitted: 22.11.2019. Accepted: 02.12.2019

cross ref http://dx.doi.org/10.14258/abs.v5.i4.6977

(C) 2019 by the authors. Submitted for possible open access publication under the terms and conditions of the

Creative Commons Attribution (CC BY) license (http://creativecommons.org/licenses/by/4.0/). 